\title{
ANTIOXIDANT ACTIVITY OF COMBINATION BANANA PEEL (MUSA PARADISIACA) AND WATERMELON RIND (CITRULLUS VULGARIS) EXTRACT IN LOTION DOSAGE FORM
}

\author{
NATALIA ALAMSYAH ${ }^{1 *}$, RATNA DJAMIL ${ }^{2}$, DENI RAHMAT ${ }^{3}$ \\ ${ }^{1}$ Faculty of Pharmacy, Pancasila University, Jakarta 12640, Indonesia. ${ }^{2}$ Departement of Biological Pharmacy, Faculty of Pharmacy, \\ Pancasila University, Jakarta 12640, Indonesia. ${ }^{3}$ Departement of Pharmaceutical Technology, Faculty of Pharmacy, Pancasila University, \\ Jakarta 12640, Indonesia. Email: natalia_alamsyah@yahoo.com \\ Received: 28 August 2016, Revised and Accepted: 14 September 2016
}

\section{ABSTRACT}

Objective: Test the antioxidant activity of banana peel extract, watermelon rind extract, and combinations, also in lotion dosage form.

Methods: The antioxidant activity of each extract and their combinations were tested with 2,2-diphenyl-1-picrylhydrazil method and formulated into a lotion dosage forms. Evaluation of the lotion dosage forms, including organoleptic, homogeneity, $\mathrm{pH}$, viscosity and rheology, microbiology, acute dermal irritation test, as well as the antioxidant activity test.

Results: Antioxidant activity test on the extract showed inhibitory concentration $50 \%\left(\mathrm{IC}_{50}\right)$ values of banana peel is 64.03 part per million (ppm) and watermelon rind extract of $300.12 \mathrm{ppm}$. Combination of banana peel and watermelon rind extract with three different concentrations, $\mathrm{IC}_{50}: \mathrm{IC}_{50^{\prime}}$ inhibitory concentration at $75 \%\left(\mathrm{IC}_{75}\right)$ :inhibitory concentration at $25 \%\left(\mathrm{IC}_{25}\right), \mathrm{IC}_{25}: \mathrm{IC}_{75}$ resulted the best antioxidant activity is a combination of banana peel, and watermelon rind extract $\mathrm{IC}_{75}: \mathrm{IC}_{25}$ with $\mathrm{IC}_{50}$ value of $177.56 \mathrm{ppm}$. The antioxidant activity test in lotion dosage form showed IC ${ }_{50}$ values of lotion base is $853.16 \mathrm{ppm}$, lotion banana peel extract is $472.50 \mathrm{ppm}$, lotion watermelon rind extract is $496.71 \mathrm{ppm}$, and the combination of banana peel and watermelon rind extract are $300.04 \mathrm{ppm}$.

Conclusion: Lotion dosage form formula that meets the requirements of quality, efficacy, and safety with the best antioxidant activity is lotion dosage form combination of banana peel and watermelon rind extract formula $\left(\mathrm{IC}_{75}: \mathrm{IC}_{25}\right)$.

Keywords: Antioxidant activity, Banana peel (Musa paradisiaca), Watermelon rind (Citrullus vulgaris), Combination of banana peel and watermelon rind extract, Lotion of antioxidant.

(C) 2016 The Authors. Published by Innovare Academic Sciences Pvt Ltd. This is an open access article under the CC BY license (http://creativecommons. org/licenses/by/4. 0/) DOI: http://dx.doi.org/10.22159/ajpcr.2016.v9s3.14926

\section{INTRODUCTION}

Damages from free radicals at the cellular level cause cel inflammation, increasing the risk of damage from sunlight radiation, and related development of skin cancer. Antioxidants work by preventing onset of disorder at the cellular level. The first body protection that most simple and flexible is on the outside of the body, that cause more appearances of antioxidant products on the market as a cosmetic preparation. But currently, a large part of preparations that available using chemical antioxidants. The development of natural antioxidants is still continuing to be studied because it is difficult to maintain the antioxidant activity of material and its stability [1-3].

Waste of yellow banana peels is rich in flavonoids and another phenolic in addition to carbohydrates, cellulose, minerals such as potassium and sodium. Flavonoid and phenolic are bioactive compounds that useful as antioxidant [4-6]. According to Yunovan, the antioxidant activity of "Kepok" banana peel extract in ethanol has inhibitory concentration $50 \%\left(\mathrm{IC}_{50}\right)$ values of 156.67 part per million (ppm) [7]. White layer of watermelon rind that is not consumed contains citrulline. Citrulline is one of the antioxidants that are beneficial for skin health [8]. According to Damayant et al. research, the antioxidant activity juice white layer of round watermelon rind has $\mathrm{IC}_{50}$ values $214.369 \mathrm{ppm}$ and oval watermelon rind is $376.266 \mathrm{ppm}$ [9]. Traditionally, watermelon that rich in water content and other fruits that rich in antioxidants such as banana can be used for skin detoxifying, providing essential nutrients to skin by moisturizing, brightening and protecting the outer layer of skin [10]. The objective of this research was to study antioxidant activity of banana peel, watermelon rind, and the combinations, also in lotion dosage form using antioxidant testing 2,2-diphenyl-1-picrylhydrazil
(DPPH) to see the stability of extract antioxidant activity when formulated into lotion dosage form.

\section{METHODS}

Chemicals and equipment

Three months old "Kepok" banana peels from Jakarta - Indonesia, white layer of three months old watermelon rinds from Central Java - Indonesia, ethanol 70\%, glyceryl monostearate (Msnchem), cera alba (Xiamen Fengstone), tween 80 (Kao Corporation), glycerin (P\&G Chemicals), paraffin liquid (Tudapetrol), nipagin (Ueno Fine Chemicals), nipasol (Ueno Fine Chemicals), parfume, water, methanol (Ajax Finechem), DPPH (Sigma-Aldrich), plate count agar (BD), potato dextrose agar (BD), semi-micro scales, blender (Philips), rotary evaporator (Buchi), freezedryer (Telstar), ultra violet-visible (UV-Vis) spectrophotometer (Shimadzu 1240), viscometer (Brookfield type RV), pH meter (Mettler Toledo).

\section{Manufacture of extract}

Banana peel extract

Banana skin was macerated using ethanol 70\% ratio 1:2 using a shaker for $24 \mathrm{~h}$ at room temperature, repeated 3 times and filtered. The filtrate was concentrated by rotary evaporator.

\section{Watermelon rind extract}

White layer of watermelon rind is refined using blender and filtered. The filtrate was powdered by freeze dryer.

Quality inspection of extract

Examinations involve in non-specific parameters are organoleptic drying shrinkage, specific gravity, water content, total ash and acid 
insoluble ash, solvent residues, pesticide residues, heavy metal contaminations, and microbial contaminations (total plate count and total yeast mold). As well as specific parameters are phytochemical screening (alkaloids, saponins, tannins, phenolics, flavonoids, triterpenoids, steroids, glycosides, essential oils, quinones, coumarin) and total flavonoid content by spectrophotometric method $[11,12]$

\section{Antioxidant activity test by DPPH method}

Antioxidant activity was tested as a release of the stable DPPH radical. In the radical form, DPPH maximum absorption at $\lambda 515 \mathrm{~nm}$. The mixture reaction $(5 \mathrm{ml})$ contain $1 \mathrm{ml}$ of $0.4 \mathrm{mM}$ DPPH $(15.8 \mathrm{mg}$ DPPH in $100 \mathrm{ml}$ of methanol) and various concentrations of test solution dissolved in methanol. After incubation 30 minutes at $37^{\circ} \mathrm{C}$ in the dark room, absorbance was measured at $\lambda 515 \mathrm{~nm}$ using UVVis spectrophotometer. Lower absorbance indicates higher restriction of free radical scavenging (\% inhibition). Determination of $\mathrm{IC}_{50}$ value using linear regression between concentration and percent inhibition by replacing the percent inhibition to 50 [13-18].

$\%$ Inhibition $=\left(\mathrm{Abs}_{\text {control }}-\mathrm{Abs}_{\text {sample }}\right) / \mathrm{Abs}_{\text {control }} \times 100 \%$

Prepare a series of test solution with a concentration of $12.5 ; 25 ; 37.5$; 50 ; and $62.5 \mathrm{mg} / \mathrm{ml}$ of banana peel extract, watermelon rind extract, combination banana peel, and watermelon rind extract.

\section{Manufacture of antioxidant lotion dosage form}

Cera alba that has been melted is poured into beaker glass containing paraffin liquid at the top of a hotplate temperature $40-60^{\circ} \mathrm{C}$ and stirrer at speed around $700 \mathrm{rpm}$. Then, add glyceryl monostearate, tween 80 glycerin, extracts which have been mixed with nipagin and nipasol, water, and perfume as fragrances (Table 1) [19].

\section{Evaluation of lotion dosage form}

Organoleptic includes examination of color, odor, and sense when an application on the skin.

Homogeneity by applying the preparation on glass object, drops of methylene blue, and observed under a microscope.

$\mathrm{pH}$ tested using a $\mathrm{pH}$ meter.

Viscosity and rheology tested using a Brookfield viscometer type RV, spindle number 4 with three different speed $(2.5,4$, and 5).

Microbiology tested of total plate count and total yeast mold with sample concentration $0.5 \mathrm{ml}$.

Acute dermal irritation test using albino rabbit (weight around $2 \mathrm{~kg}$ ) with test dose $0.5 \mathrm{~g}$. Response rating on 1, 24, 48, and $72 \mathrm{~h}$ after the opening of the patch. Ethical clearance approval from Airlangga University, Surabaya - Indonesia.

Table 1: Formulation of antioxidant lotion dosage form

\begin{tabular}{lllll}
\hline \multirow{2}{*}{ Formula materials } & \multicolumn{5}{l}{ Composition (\%) } \\
\cline { 2 - 5 } & F1 & F2 & F3 & F4 \\
\hline Banana peel extract & - & $12.81 \mathrm{mg}$ & - & $13.86 \mathrm{mg}$ \\
Watermelon rind extract & & - & $60.02 \mathrm{mg}$ & $21.65 \mathrm{mg}$ \\
Glyceryl monostearate & 2.8 & 2.8 & 2.8 & 2.8 \\
Cera alba & 7.5 & 7.5 & 7.5 & 7.5 \\
Tween 80 & 4.7 & 4.7 & 4.7 & 4.7 \\
Glycerin & 10 & 10 & 10 & 10 \\
Paraffin liquid & 10 & 10 & 10 & 10 \\
Nipagin & 0.15 & 0.15 & 0.15 & 0.15 \\
Nipasol & 0.15 & 0.15 & 0.15 & 0.15 \\
Parfume & Qs & qs & qs & qs \\
Water ad (ml) & 100 & 100 & 100 & 100 \\
\hline
\end{tabular}

Antioxidant activity test of preparation using DPPH method with test solution concentration $20,40,60,80$, and $100 \mu \mathrm{g} / \mathrm{ml}$.

\section{RESULTS}

Table 2 shows examination results of extract. A study of antioxidant activity of banana peel extract, watermelon rind extract, and their combinations are shown in Table 3. The combination of banana peel and watermelon rind extract with three different combinations based on the comparison IC value of its single extract, which combination of banana peel:watermelon rind extract with a ratio of $\mathrm{IC}_{50}: \mathrm{IC}_{50}$, inhibitory concentration $75 \%\left(\mathrm{IC}_{75}\right)$ :Inhibitory concentration $25 \%\left(\mathrm{IC}_{25}\right)$, and $\mathrm{IC}_{25}: \mathrm{IC}_{75}$. Banana peel extract, watermelon rind extract, and the best combination of banana peel and watermelon rind extract (combination of banana peel:watermelon extract [75:25]) are formulated into lotion dosage form. Evaluation of lotion dosage form include organoleptic (Fig. 1 and Table 4), homogeneity (Table 5), pH (Table 6), viscosity (Table 7) and rheology (Fig. 2), microbiology (Table 8), acute dermal irritation (Table 9), also antioxidant activity test of preparation (Table 10).

\section{DISCUSSION}

The result from organoleptic and homogeneity test between lotion formulas showed that there was no significant difference which is white-like milk color, typically weak odor, soft and non-sticky feel when applied to the skin, and the preparation is homogeneous with emulsion type $\mathrm{O} / \mathrm{W}$ (oil in water). The soft feeling in lotion shows that glycerin as humectant and paraffin liquid as emollient is function properly. Non-sticky feeling is because the base of lotion is $0 / \mathrm{W}$ (oil in water) with a composition ratio of water: oil around $80: 20 \mathrm{pH}$ of lotion between 5.0 and 5.5 which are in range $\mathrm{pH}$ of skin acid mantle (4.5-6.5) so expectantly the lotion will not damage the skin acid mantle layer. Test results show the viscosity of formula lotion F1> F3> F2> F4. Formula F1 (base of lotion) resulted in the most viscous lotion. Extract of banana peel and watermelon rind are hydrophilic which causing an attractive force to water molecules with a base of lotion, so the viscosity becomes more aqueous. Rheology of lotion is plastic. Characteristic chart of plastic rheology

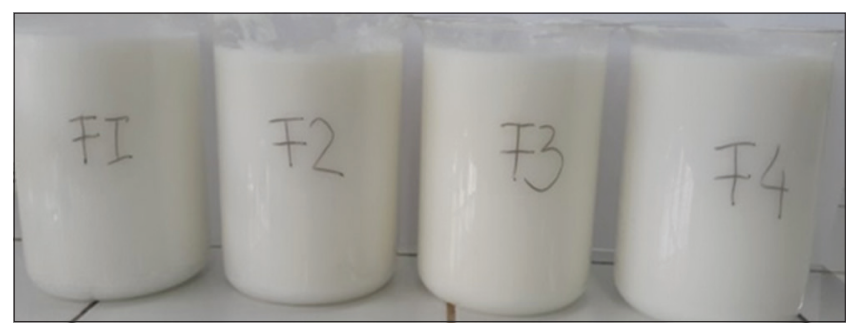

Fig. 1: Antioxidant lotion dosage form. F1: Formula 1 is a control, base of lotion without addition of extract. F2: Formula 2 is a

lotion banana peel extract. F3: Formula 3 is a lotion watermelon rind extract. F4: Formula 4 is a lotion combination of banana peel:watermelon rind extract ratio inhibitory concentration at $25 \%$ :inhibitory concentration at $75 \%$

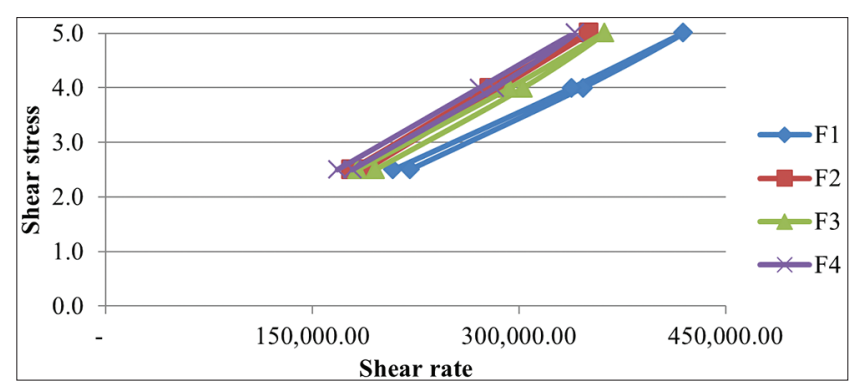

Fig. 2: Rheology of lotion 
Table 2: Quality inspection of extract

\begin{tabular}{|c|c|c|c|c|}
\hline \multirow[t]{2}{*}{ No } & \multirow[t]{2}{*}{ Type of testing } & \multicolumn{2}{|l|}{ Results } & \multirow[t]{2}{*}{ Method } \\
\hline & & Banana peel & Watermelon rind & \\
\hline \multirow[t]{3}{*}{1} & Organoleptic & & & Organoleptic \\
\hline & Color & Dark brown & Yellow & \\
\hline & Odor & Latex aromatic & Watermelon aromatic & \\
\hline 2 & Drying shrinkage & $39.66 \%$ & $39.91 \%$ & Oven $105^{\circ} \mathrm{C}$ \\
\hline 3 & Specific gravity & $1.07 \mathrm{~g} / \mathrm{ml}$ & $1.12 \mathrm{~g} / \mathrm{ml}$ & Pycnometer \\
\hline 4 & Water content & $19.96 \%$ & $33.30 \%$ & Karl-Fisher \\
\hline 5 & Total ash & $2.92 \%$ & $2.25 \%$ & Gravimetry \\
\hline 6 & Acid insoluble ash & $0.08 \%$ & $0.51 \%$ & Gravimetry \\
\hline 7 & Solvent residues & Not detected & Not detected & GC \\
\hline \multirow[t]{2}{*}{8} & Pesticide residues & & & LC MS/MS \\
\hline & Organophosphates & Not detected & Not detected & \\
\hline \multirow[t]{2}{*}{9} & Heavy metal contaminations & & & ICP-OES \\
\hline & $\mathrm{Pb}, \mathrm{Cd}, \mathrm{Sn}, \mathrm{HG}, \mathrm{As}$ & Not detected & Not detected & \\
\hline \multirow[t]{2}{*}{10} & Microbial contaminations & & & Total count \\
\hline & Total yeast mold & $<10 \mathrm{cfu} / \mathrm{ml}$ & $<10 \mathrm{cfu} / \mathrm{ml}$ & \\
\hline 11 & Total flavonoid & $0.129 \%$ & $0.133 \%$ & Spectrophotometric \\
\hline \multirow{12}{*}{12} & Phytochemical screening & & & Qualitative \\
\hline & Alkaloids & + & + & \\
\hline & Saponins & + & + & \\
\hline & Tannins & + & - & \\
\hline & Phenolics & + & - & \\
\hline & Flavonoids & + & + & \\
\hline & Triterpenoids & + & + & \\
\hline & Steroids & - & - & \\
\hline & Glycosides & - & - & \\
\hline & Essential oils & - & - & \\
\hline & Quinones & - & - & \\
\hline & Coumarin & - & - & \\
\hline
\end{tabular}

GC: Gas chromatography, LC-MS/MS: Liquid chromatography-mass spectrometry/mass spectrometry, ICP-OES: Inductively coupled plasma-optical emission spectrometry, cfu: Colony forming unit

Table 3: Antioxidant activity test of extract

\begin{tabular}{ll}
\hline Material & IC $_{50}(\mathbf{p p m})$ \\
\hline Banana peel extract & $64.03 \pm 2.78$ \\
Watermelon rind extract & $300.12 \pm 15.32$ \\
Combination of banana peel: watermelon rind extract $\left(\mathrm{IC}_{50}: \mathrm{IC}_{50}\right)$ & $226.82 \pm 18.60$ \\
Combination of banana peel: watermelon rind extract $\left(\mathrm{IC}_{75}: \mathrm{IC}_{25}\right)$ & $177.56 \pm 10.20$ \\
Combination of banana peel: watermelon rind extract $\left(\mathrm{IC}_{25}: \mathrm{IC}_{75}\right)$ & $292.52 \pm 2.91$ \\
\hline $\mathrm{IC}_{75}:$ Inhibitory concentration at $75 \%, \mathrm{IC}_{25}:$ Inhibitory concentration at $25 \%, \mathrm{IC}_{50}:$ Inhibitory concentration at 50\%, ppm: Part per million
\end{tabular}

Table 4: Organoleptic of lotion

\begin{tabular}{lllll}
\hline Formula & F1 & F2 & F3 & F4 \\
\hline Color & White-like milk & White-like milk & White-like milk & White-like milk \\
Odor & Typically weak & Typically weak & Typically weak & Typically weak \\
Sense & Not sticky & Not sticky & Not sticky & Not sticky \\
\hline
\end{tabular}

Table 5: Homogeneity of lotion

\begin{tabular}{lllll}
\hline Formula & F1 & F2 & F3 & F4 \\
\hline Homogeneity & Homogeneous & Homogeneous & Homogeneous & Homogeneous \\
Emulsion type & O/W & O/W & O/W & 0/W \\
\hline
\end{tabular}

Table 6: pH of lotion

\begin{tabular}{lllll}
\hline Formula & F1 & F2 & F3 & F4 \\
\hline $\mathrm{pH}$ & $5.26 \pm 0.06$ & $5.27 \pm 0.03$ & $5.29 \pm 0.04$ & $5.27 \pm 0.08$ \\
\hline
\end{tabular}


Table 7: Viscosity of lotion

\begin{tabular}{lllll}
\hline Formula & F1 & F2 & F3 & F4 \\
\hline Viscosity (cps) & $23,765.00 \pm 1,192$ & $19,931.76 \pm 490$ & $20,753.33 \pm 1,276$ & $19,235.00 \pm 1,437$ \\
\hline cps: Centi poise & & &
\end{tabular}

Table 8: Microbiology of lotion

\begin{tabular}{lllll}
\hline Formula & F1 & F2 & F3 & \\
\hline TPC $(\mathrm{cfu} / \mathrm{ml})$ & $<10$ & $<10$ & $<10$ & $<10$ \\
TYM $(\mathrm{cfu} / \mathrm{ml})$ & $<10$ & $<10$ & $<10$ & $<10$ \\
\hline
\end{tabular}

cfu: Colony forming unit, TPC: Total plate count, TYM: Total yeast mold

Table 9: Acute dermal irritation test of lotion

\begin{tabular}{lllll}
\hline Formula & F1 & F2 & F3 & \\
\hline Primary irritation index & 0 & 0 & 0 & F4 \\
\hline
\end{tabular}

Table 10: Antioxidant activity test of lotion

\begin{tabular}{lllll}
\hline Formula & F1 & F2 & F3 & F4 \\
\hline IC50 $(\mathrm{ppm})$ & $853.16 \pm 12.99$ & $472.50 \pm 28.48$ & $496.71 \pm 39.88$ & $300.04 \pm 5.51$ \\
\hline
\end{tabular}

IC50: Inhibitory concentration at 50\%, ppm: Part per million

is consistency curve for plastic material not passing through the point $(0,0)$ but intersects the shearing stress axis (or will be cut off if the straight part of the curve is extrapolated to the axis) at a point known as yield value. The preparation will not flow until the shearing stress is achieved by yield value. This plastic rheology is characteristic of cera alba that used in the base of lotion, when idle and low temperatures, these materials tend to be a flocculation form. Microbiology test shows the growth of microorganisms $<10 \mathrm{cfu} / \mathrm{ml}$, so qualify according to "A Guidance Document on Microbiological Control of Cosmetic Products" that limit of microorganisms (bacteria, yeasts, and molds) in leave-on product should not more than 100 $\mathrm{cfu} / \mathrm{ml}$ in $0.5 \mathrm{ml}$ of product. This shows that nipagin and nipasol used in lotion worked effectively to keep the lotion from microorganism growth. Acute dermal irritation test shows the primary irritation index is zero, means no indication of erythema and edema, it can be categorized as very mild irritation response.

The best antioxidant activity of extract is banana peel extract with $\mathrm{IC}_{50}$ value $64.03 \mathrm{ppm}$. The results of antioxidant activity test of lotion, formula F1 is base of lotion do not have antioxidant activity so in conclusion that the base of lotion is not affecting antioxidant activity of extract in lotion dosage form. Antioxidant activity of formula F2, F3, and F4 decreased if compare with antioxidant activity of extract. Formula F2 using banana peel extract has decreased approximately 7.4. Formula F3 using watermelon rind extract and formula F4 is a combination of banana peel and watermelon rind extract have decreased approximately 1.7. Watermelon rind extract and combinations extract when formulated into a lotion dosage form are decreased smaller than banana peel extract. It can be concluded that the antioxidant activity of banana peel extract can be protected by watermelon rind extract of decomposition, so the combination of both extracts shows the highest antioxidant activity in lotion dosage form. The antioxidant activity of extract can not guarantee the stability of antioxidant activity when formulation into a dosage form.

\section{CONCLUSION}

Banana peel extract with the highest antioxidant activity when formulated into lotion has significant decrease of antioxidant activity, but when combined with watermelon rind extract has better antioxidant activity.

\section{REFERENCES}

1. Asim K. Antioxidant Natural and Syntetic. Germany: Armani International Publisher Kiel; 2006. p. 61-83.

2. Mandal S, Yadav S, Nema RK. Antioxidants: A review. J Chem Pharm Res 2009;1(1):102-4.

3. Wanasundara PK, Shahidi F. Antioxidants: Science, Technology, and Applications [e-Book]. $6^{\text {th }}$ ed. New York: John Wiley \& Sons, Inc.; 2005. p. 431-74.

4. Nurjanah S. Ekstraksi Dan Karakterisasi Pati Pisang Ambon (Musa paradisiaca var. Sapientum) [Skripsi]. Bogor: Fakultas Teknologi Pertanian Institut Pertanian Bogor; 1991.

5. Azmi NA. Extraction of Antioxidant Activity, Phenolic Content and Minerals in Banana Peel [Thesis]. Malaysia: Faculty of Chemical and Natural Resources Engineering Universiti Malaysia Pahang; 2010. p. 9-12.

6. Someya S, Yoshiki Y, Okubo K. Antioxidant compounds from banana. Food Chem 2002;79(3):351-4.

7. Yunovan N. Isolasi Dan Identifikasi Senyawa Penghambat Enzim $\alpha$-glukosidase Pisang Kepok (Musa Paradisiaca ABB) [Skripsi]. Jakarta: Fakultas Farmasi Universitas Pancasila; 2014

8. Singh R, Kumar JC, Nandpuri KS. A study on the influence of the structural chemical constituents of the skin of watermelon (Citrullus lanatus Sch.) Fruit on the incidence of its blossom-end-rot and cracking. Indian J Hortic 1975;32(1-2):98-101.

9. Ismayanti I, Bahri S, Nurhaeni N. The study of phenolics content and antioxidant activities of watermelon rind juice (Citrullus lanatus). Online J Nat Sci 2013;2(2):36-45.

10. Lim YY, Lim TT, Tee JJ. Antioxidant properties of several tropical fruits: A comparative study. Food Chem 2007;103(3):1003-8.

11. Harborne JB. Phytochemical Methods: A Guide to Modern Techniques of Plant Analysis. 2nd ed. London: Chapman \& Hall; 1984.

12. Vinson JA, Su X, Zubik L, Bose P. Phenol antioxidant quantity and quality in foods: Fruits. J Agric Food Chem 2001:49(11):5315-21.

13. Blois MS. Antioxidant determination by the use of stable free radicals. Nature 1958;181:1199-2000.

14. Kochhar SP, Rossell JB. Detection, estimation and evaluation of antioxidants in food systems. In: Hudson BJ, editor. Food Antioxidants. London and New York: Elsevier Applied Science; 1990. p. 19-64.

15. Hodisan T, Juncan AM. Analysis of Some Antioxidants Used in Cosmetics by Chromatographic Methods [Thesis]. Romania: Faculty of Chemistry and Chemical Engineering University Cluj-Napoca; 2011. p. $10-1$.

16. Khatua S, Roy T, Acharya K. Antioxidant and free radical scavenging capacity of phenolic extract from Russula laurocerasi. Asian J Pharm Clin Res 2013;6(4):156-60. 
17. Abirami MS, Muthuswamy M. Antioxidant potential, total phenolic and total flavonoids content of various extracts from whole plant of Polycarpaea corymbosa Lam. Asian J Pharm Clin Res 2013;6(4):121-4

18. Fidrianny I, Harnovi M, Insanu M. Evaluation of antioxidant activities from various extracts of sweet orange peels using DPPH, frap assays and correlation with phenolic, flavonoid, carotenoid content. Asian J Pharm Clin Res 2014;7(3):186-90.

19. Mitsui T. New Cosmetic Science. Amsterdam: Elsevier; 1997. p. $327-31$. 